\title{
Perkembangan Jaringan
}

Muji Setia

175100027

Fakultas Komputer

Mahasiswa@institusi.ac.id

\begin{abstract}
Dalam kehidupan sehari-hari kita tidak terlepas dari komunikasi. Komunikasi merupakan hal yang sangat penting dalam suatu kehidupan manusia karena dengan komunikasi seseorang bisa saling berinteraksi satu sama lain. Komunikasi bisa dilakukan secara langsung dengan tatap muka dan juga bisa lewat jarak jauh. Untuk melaksanakan komunikasi jarak jauh tersebut dibutuhkan alat yang bisa menghubungkan kita dengan orang lain yang jaraknya cukup jauh.

Komunikasi awalnya bergantung pada transportasi jalan antar kota, antar provinsi/negara bahkan kemudian antar negara/benua. Kemudian komunikasi dapat terjadi jarak jauh melalui telegraf (1844), telepon (1867), gelombang radio elektromagnetik (1889), radio komersial (1906), televisi broadcast (1931), kemudian melalui televisi, dunia jadi lebih kecil karena orang dapat mengetahui dan mendapatkan informasi tentang yang terjadi di bagian lain dunia ini.

Dalam telekomunikasi, informasi disampaikan melalui sinyal. Sinyal ada dua macam, sinyal digital dan sinyal analog. Sinyal digital yaitu sinyal yang diwakili oleh angka 0 dan 1. Sedangkan sinyal analog yaitu sinyal yang terus menerus dengan variasi kekuatan dan kualitas misalnya suara, cahaya, suhu yang dapat berubah-ubah kualitasnya. Data analog dikirimkan dalam bentuk yang berkelanjutan, sinyal elektrik berkelanjutan dalam bentuk gelombang. Televisi, telepon dan radio adalah teknologi telekomunikasi yang menggunakan sinyal analog, sedang komputer menggunakan sinyal digital untuk transfer informasi.

Namun saat ini sinyal digital juga digunakan untuk suara, gambar dan gabungan keduanya. Di sisi lain, komputer yang awalnya dimanfaatkan sebagai mesin penghitung dan pengolah data, digunakan sebagai alat komunikasi sejak adanya jaringan komputer.
\end{abstract}

Kata Kunci : perkembangan jaringan 


\section{Fakultas Komputer \\ TUGAS 1 - 88675543}

\section{A. PENDAHULUAN}

Teknologi yg berkembang saat ini tentunya dapat mempermudah dan memaksimalkan dalam melakukan berbagai hal dalam kehidupan sehari - hari, termasuk dalam hal mengakses berbagai informasi maupun data. PC (Personal computer) merupakan salah satu alat yang yang sering digunakan dalam mengakses berbagai data maupun informasi saat ini. Dengan PC maka kita dengan mudah mengakses berbagai data maupun informasi, namun data maupun informasi yang dapat di akses sangatlah terbatas atau tidak dapat mengakses informasi dari luar PC itu sendiri. Dengan menggunakan sebuah media jaringan internet maka akses data maupun informasi dari luar dapat kita akses dengan mudah.

Dengan memanfaatkan perkembangan jaringan komputer untuk berkoneksi dengan internet saat ini, data maupun informasi dapat

\section{B. PEMBAHASAN / STUDI KASUS}

Teknologi yg berkembang saat ini tentunya dapat mempermudah dan memaksimalkan dalam melakukan berbagai hal dalam kehidupan sehari - hari, termasuk dalam hal mengakses berbagai informasi maupun data. PC (Personal computer) merupakan salah satu alat yang yang sering digunakan dalam mengakses berbagai data maupun informasi saat ini. Dengan PC maka kita dengan mudah mengakses berbagai data maupun informasi, namun data maupun informasi yang dapat di akses sangatlah terbatas atau tidak dapat mengakses informasi dari luar PC itu sendiri. Dengan menggunakan sebuah media jaringan internet maka akses data maupun informasi dari luar dapat kita akses dengan mudah.

Dengan memanfaatkan perkembangan jaringan komputer untuk berkoneksi dengan internet saat ini, data maupun informasi dapat kita akses dengan cepat, mudah, dan akurat. Sampai saat ini akses untuk ke internet terus
Muji Setia

kita akses dengan cepat, mudah, dan akurat. Sampai saat ini akses untuk ke internet terus berkembang. Ada berbagaimana macam tipe koneksi ke internet, baik yang mengunakan kabel (wire) maupun yang tanpa kabel (wireless).

Oleh karena itu, kita akan membahas tentang tipe akses ke internet. Namun perkembangan tipe akses ke internet yang akan kami bahas dalam artikel ini tipe akses tanpa kabel (wireless) atau lebih tepatnya wireless LAN ( wifi). Perkembangan wireless LAN dimulai sejak tahun 70'an oleh IBM yang mengeluarkan hasil percobaan mereka dalam merancang WLAN dengan teknologi IR, perusahaan lain seperti Hewlett-Packard (HP) menguji WLAN dengan RF. Perjalanan perkembangan wireless LAN terjadi cukup lama sehingga mencapai kecepatan akses yang lebih sempurna.

berkembang. Ada berbagaimana macam tipe koneksi ke internet, baik yang mengunakan kabel (wire) maupun yang tanpa kabel (wireless).

Oleh karena itu, kita akan membahas tentang tipe akses ke internet. Namun perkembangan tipe akses ke internet yang akan kami bahas dalam artikel ini tipe akses tanpa kabel (wireless) atau lebih tepatnya wireless LAN ( wifi). Perkembangan wireless LAN dimulai sejak tahun 70'an oleh IBM yang mengeluarkan hasil percobaan mereka dalam merancang WLAN dengan teknologi IR, perusahaan lain seperti Hewlett-Packard (HP) menguji WLAN dengan RF. Perjalanan perkembangan wireless LAN terjadi cukup lama sehingga mencapai kecepatan akses yang lebih sempurna.

Sejarah Perkembangan Wireless LAN ( WiFi )

Pada akhir 1970-an IBM mengeluarkan hasil percobaan mereka dalam merancang WLAN dengan teknologi IR, perusahaan lain seperti Hewlett-Packard (HP) menguji WLAN dengan RF. Kedua 
$\stackrel{*^{*} *}{2}$ Fakultas Komputer

$\Longleftrightarrow$ TUGAS 1 - 88675543

perusahaan tersebut hanya mencapai data rate 100 Kbps. Karena tidak memenuhi standar IEEE 802 untuk LAN yaitu 1 Mbps maka produknya tidak dipasarkan. Baru pada tahun 1985, (FCC) menetapkan pita Industrial, Scientific and Medical (ISM band) yaitu 902928 MHz, 2400-2483.5 MHz dan 5725-5850 $\mathrm{MHz}$ yang bersifat tidak terlisensi, sehingga pengembangan WLAN secara komersial memasuki tahapan serius. Barulah pada tahun 1990 WLAN dapat dipasarkan dengan produk yang menggunakan teknik spread spectrum (SS) pada pita ISM, frekuensi terlisensi 18-19 GHz dan teknologi IR dengan data rate $>1$ Mbps.

Pada tahun 1997, sebuah lembaga independen bernama IEEE membuat spesifikasi/standar WLAN pertama yang diberi kode 802.11. Peralatan yang sesuai standar 802.11 dapat bekerja pada frekuensi 2,4GHz, dan kecepatan transfer data (throughput) teoritis maksimal 2Mbps.

Pada bulan Juli 1999, IEEE kembali mengeluarkan spesifikasi baru bernama 802.11b. Kecepatan transfer data teoritis maksimal yang dapat dicapai adalah 11 Mbps. Kecepatan tranfer data sebesar ini sebanding dengan Ethernet tradisional (IEEE 802.3 10Mbps atau 10Base-T). Peralatan yang menggunakan standar $802.11 \mathrm{~b}$ juga bekerja pada frekuensi 2,4Ghz. Salah satu kekurangan peralatan wireless yang bekerja pada frekuensi ini adalah kemungkinan terjadinya interferensi dengan cordless phone, microwave oven, atau peralatan lain yang menggunakan gelombang radio pada frekuensi sama.

Pada saat hampir bersamaan, IEEE membuat spesifikasi 802.11a yang menggunakan teknik berbeda. Frekuensi yang digunakan 5Ghz, dan mendukung kecepatan transfer data teoritis maksimal sampai $54 \mathrm{Mbps}$. Gelombang radio yang dipancarkan oleh peralatan $802.11 \mathrm{a}$ relatif sukar menembus dinding atau penghalang lainnya.
Muji Setia

Jarak jangkau gelombang radio relatif lebih pendek dibandingkan 802.11 b. Secara teknis, 802.11b tidak kompatibel dengan 802.11a. Namun saat ini cukup banyak pabrik hardware yang membuat peralatan yang mendukung kedua standar tersebut.

Pada tahun 2002, IEEE membuat spesifikasi baru yang dapat menggabungkan kelebihan 802.11b dan 802.11a. Spesifikasi yang diberi kode 802.11g ini bekerja pada frekuensi 2,4Ghz dengan kecepatan transfer data teoritis maksimal 54Mbps. Peralatan 802.11g kompatibel dengan 802.11b, sehingga dapat saling dipertukarkan. Misalkan saja sebuah komputer yang menggunakan kartu jaringan 802.11g dapat memanfaatkan access point $802.11 \mathrm{~b}$, dan sebaliknya.

Pada tahun 2006, 802.11n dikembangkan dengan menggabungkan teknologi 802.11b, 802.11g. Teknologi yang diusung dikenal dengan istilah MIMO (Multiple Input Multiple Output) merupakan teknologi Wi-Fi terbaru. MIMO dibuat berdasarkan spesifikasi Pre-802.11n. Kata "Pre-" menyatakan "Prestandard versions of 802.11n". MIMO menawarkan peningkatan throughput, keunggulan reabilitas, dan peningkatan jumlah klien yg terkoneksi. Daya tembus MIMO terhadap penghalang lebih baik, selain itu jangkauannya lebih luas sehingga Anda dapat menempatkan laptop atau klien Wi-Fi sesuka hati. Access Point MIMO dapat menjangkau berbagai perlatan Wi-Fi yg ada disetiap sudut ruangan. Secara teknis MIMO lebih unggul dibandingkan saudara tuanya $802.11 \mathrm{a} / \mathrm{b} / \mathrm{g}$. Access Point MIMO dapat mengenali gelombang radio yang dipancarkan oleh adapter Wi-Fi 802.11a/b/g. MIMO mendukung kompatibilitas mundur dengan $802.11 \mathrm{a} / \mathrm{b} / \mathrm{g}$. Peralatan Wi-Fi MIMO dapat menghasilkan kecepatan transfer data sebesar 108Mbps.

Surat kabar, buku, radio dan telelvisi sudah merupakan bagian kehidupan sehari-hari bagi sebagian besar masyarakat Indonesia. Dengan bertambah canggihnya teknolgi 
mikroelektronika, fax dan komputer akan mengambil porsi yang cukup besar dalam dunia informasi di Indonesia. Lima tahun yang lalu, nomor telepon di perkantoran yang khusus digunakan untuk fax masih sangat langka. Saat ini, nomor telepon fax sudah merupakan hal yang lazim digunakan di perkantoran. Hal ini menunjukkan bahwa informasi memegang peranan dalam beberapa bidang penting, seperti bidang usaha, industri dan pendidikan.

Kelancaran proses alih informasi dan pengolahan data akan sangat membantu perkembangan dunia usaha, industri dan pendidikan untuk banyak hal. Proses alih informasi dan pengolahan data akan lebih cepat jika berlangsung antar komputer dibandingkan dengan fax. Dengan demikian, bukan hal yang tidak mungkin jika saluran khusus untuk komunikasi antarkomputer (lebih dikenal sebagai jaringan komputer) merupakan hal yang lazim di masa mendatang.

Untuk memungkinkan komunikasi antarkomputer, prasarana jaringan komputer meliputi wilayah luas perlu dikembangkan. Beberapa alternatif telah dicoba dikembangkan, seperti SKDP (PT Telkom) dan tak lama lagi di beberapa daerah kecil akan beroperasi sistem ISDN (juga dikelola oleh PT Telkom). Alternatif lain yang cukup menarik untuk dikaji adalah jaringan komputer paket radio yang saat ini digunakan oleh tidak kurang dari 2400 orang di seluruh Indonesia, dengan komposisi pengguna sebagai berikut: 69 persen pengguna di perguruan tinngi, 18 persen pengguna di lembaga pemerintah, 4 persen pengguna di lembaga pemerintahan, 4 persen pengguna di lembaga swadaya masyarakat (LSM), dan 5 persen pengguna berada di industry / badan komersial.

Teknologi yang digunakan pada jaringan komputer merupakan perkembangan teknologi SKDP (PT Telkom). Protokol AX.25 digunakan pada link layer, yang merupakan protokol X.25 (SKDP). Diatas protokol
AX.25, digunakan protokol (Internet Protokol) yang memungkinkan integrasi berbagai jenis komputer ke dalam jaringan. Adapun aplikasi utama yang dijalankan dalam jaringan komputer ini adalah:

1. Surat elektronik;

2. Diskusi / konferensi secara elektronik;

3. Pengiriman berkas / file secara elektronik;

4. Akses pada distributed database; dan

5. Fasilitas talknet untuk kerja pada komputer yang berjauhan.

Satu hal yang membedakan aplikasi jaringan komputer dengan teknologi lainnya adalah tidak adanya batasan dimensi ruang dan waktu. Sebagai contoh, diskusi / seminar / konferensi secara elektronik dapat berlangsung kapan saja, di mana saja bahkan tidak terikat pada batas-batas negara. Globalisasi sangat terasa dengan adanya jaringan komputer.

Tata cara komunikasi merupakan faktor penting pada pengkaitan jaringan komputer lokal di gedung-gedung. Pemilihan tata cara komunikasi dilakukan dengan memperhitungkan kompatibilitas dengan cara komnukasi yang umum digunakan. Saat ini, tata cara komunikasi TCP / IP merupakan standar yang digunakan di jaringan-jaringan komputer lokal di gedung-gedung. TCP / IP mulai dikembangkan sekitar sepuluh tahun lalu atas biaya angkatan bersenjata Amerika Serikat. TCP / IP mengatur pengkaitan berbagai komputer dalam jaringan yang terkait wilayah luas tanpa tergantung pada jenis saluran fisik yang digunakan. Keandalan jaringan diawasi secara seksama selama prosees komunikasi berlangsung. Berbagai penggunaan, seperti pengiriman surat elektronik dan file antarkomputer dapat dilakukan dengan mudah menggunakan TCP / IP. Jelas bahwa proses pengembangan jaringan komputer wilayah luas akan sangat dipermudah dengan mengadopsi tata cara komunikasi standar seperti TCP/IP.

TCP/IP saat ini tengah giat dipelajari dan dikembangkan, antara lain di Computer Network Research Group, PAU 
Mikroelektronika ITB. Keterangan cukup lengkap, berupa buku dan file di disket komputer, source code perangkat TCP / IP dapat diperoleh secara nonkomersial dari lembaga tersebut. Perangkat lunak beserta source code (file program) TCP/IP untuk komputer mikro dapat diperoleh secara nonkomersial untuk penggunaan di dunia pendidikan dan amatir radio. Pengembangan perangkat lunak ini tengah dilakukan di lembaga tersebut untuk membuka kemungkinan pengkaitan jaringan komputer lokal di berbagai gedung perkantoran menggunakan radio. 


\section{E. DISKUSI}

\section{KESIMPULAN}

Dari makalah ini kami menyimpulkan, bahwa:

- Jaringan komputer memiliki beberapa manfaat, yaitu bisa melakukan proses pengiriman data secara cepat dan efisien, membantu berhubungan dan berkomunikasi dengan orang lain, dll.

- Klasifikasi jaringan komputer dibedakan berdasarkan geografisnya, fungsi, media transmisi yang digunakan, distribusi sumber informasi/data, dan topologi jaringan.

\section{F. REFERENCE}

Desi Nilawati.2014."Apa itu TCP/IPV4 dan IPV6".http://desinilawati.blogspot.com/201 3/12/apa-itu-tcpipv4-dan-ipv6.html Stevanni Amelia.2014."Analisis dan Desain IPV4".http://stevanniamelia.blogspot.com/2 014/10/analisis-dan-desain-ipv4.html Candra Setiawan.2009.'IPV4 Packet Header'.http://pekoktenan.wordpress.com/ 2009/03/31/ip-packet-header/
Teman saya bernama ghata berpendapat tentang mengenai perkembangan jarinagan Internet adalah seluruh jaringan yang saling terhubung satu sama lain. Beberapa komputerkomputer dalam jaringan ini menyimpan file, seperti halaman web, yang dapat diakses oleh seluruh jaringan komputer. 